\title{
TITLE:
}

\section{Opening Address by Professor Hosea Kayumbo University of Dar- es-Salaam}

$\operatorname{AUTHOR}(\mathrm{S})$ :

\section{CITATION:}

Opening Address by Professor Hosea Kayumbo University of Dar-esSalaam. Pan Africa News 1995, 2(1): 2-3

ISSUE DATE:

1995-06

URL:

http://hdl.handle.net/2433/143317

RIGHT:

Copyright (C) Pan Africa News. 


\section{Inauguration of the}

\section{Mahale Wildlife Conservation society}

\author{
Opening Address by Professor Hosea Kayumbo \\ University of Dar-es-Salaam
}

Ladies and Gentlemen.

I have the honour to welcome you here to witness the inauguration of the Mahale Wildlife Conservation Society. On behalf of the interim committee I wish to express our sincere appreciation to you for accepting our invitation at such short notice. We hope you will continue to support the Society in its endeavour to achieve its objectives which are mainly to promote activities aimed at maintaining the Mahale Mounatins as a reserve of flora and fauna, especially chimpanzees.

The idea of establishing a society was first mentioned to me by Professor Nishida in 1984 during my visit to his Laboratory in Tokyo. At that time Professor Nishida, who has spent the past 28 years carrying out extensive research at Mahale on chimpanzee behaviour and their life history strategies, was concerned that there were no Tanzanian scientists on the long-term research team. We both felt obliged to look for ways to get more active participation and cooperation from local scientists. Hence, the suggestion that we should start this Society and invite all interested parties to join. It has taken us several years to draft the constitution and have it registered with the registrar of societies in Tanzania. In this regard I wish to pay tribute to three of my colleagues: Mr. Edeus Massawe, Mr. Rogath Olomi and Mr. T. Nemoto who drafted the constitution of the Society and convinced the registrar of societies of the need to have such a society in Tanzania. Our counterparts in Japan, who are mainly scientists at Kyoto University have gone a step further and launched a newsletter (copies of which will be sent to you if you will kindly let us have your mailing addresses). Through the newsletter it is hoped to promote public awareness and even involvement in the conservation of primates (especially chimpanzees) and their habitat in the Mahale area.
We have been particularly heartened by the encouragement we have received from Hon. Msambya, Member of Parliament for Kigoma South which includes Mahale. We have also received support from the Director of Wildlife Services, Mr. Ndolanga whose ministry has always had a keen interest in the conservation of this rapidly disappearing species of ape.

Colleagues in my department have shown a keen interest in the establishment of the Society. Special mention should be made of Professor Kim Howell, Professor Nikundiwe, Dr. Urasa, Dr. Mturi and Dr. Sentoza.

The Ambassador of Japan has shown keen interest in Mahale although he has not been in Tanzania for very long. We are very grateful for his interest and committment to the cause of the conservation of Mahale.

May I also take this opportunity to thank members of the local press and TV for the keen interest they have taken in our efforts to establish the Society. Yesterday the Daily News printed a small advertisement on our behalf at a reduced price. We are grateful to them for this gesture. I very much hope that the media in future will give wider coverage to the activities of the Society in order to create public awareness of conservation in Tanzania, and in particular, in the Mahale area where chimpanzees and other primates are found in the wild.

Let me now take a few minutes to say a few words on Mahale. Mahale is a designated National Park within which has been set up the Mahale Mountain Wildlife Research Centre. The park lies $150 \mathrm{~km}$ south of Kigoma along the eastern shores of Lake Tanganyika. Its elevation ranges from about $800 \mathrm{~m}$ to $2,460 \mathrm{~m}$ above sea level. It is characterised by extremely diverse vegetation with many endemic or unique plant species. The ideal vegetation for the survival of the chimpanzee is comprised of 'semideciduous' or 'semi-evergreen' gallery forest found between $780 \mathrm{~m}$ to $1300 \mathrm{~m}$ above sea level. In the 
monograph recording 25 years of research in the Mahale Mountains, Nishida has described Mahale as being biogoegraphically one of the most interesting regions in East Africa, with its animal and plant communities showing similarities to those of West Africa. Besides the chimpanzee there are other interesting primates including the Angolan black and white colobus which is not found anywhere else in Tanzania.

Also there are many endemic species of insects (butterflies, beetles, bees etc.) - species not found anywhere else in the world. All in all the number of mammals recorded at Mahale are as follows:

$\begin{array}{lc}\text { Primates } & 9 \\ \text { Pangolins } & 1 \\ \text { Rodents } & 9 \\ \text { Carnivores } & 16 \\ \text { Hippopotamus } & 1 \\ \text { Ungulates } & 7 \\ \text { Aardvark } & 1 \\ \text { Elephant } & 1 \\ \text { Dassie } & 2 \\ \text { Zebra } & 1 \\ \text { Pigs } & 2\end{array}$

(Not much is known about bats, shrews and some rodents).

One point worth noting is that the Japanese pioneers of this sustained 30 years research at Mahale, notably Itani, Nishida, Uehara, Takahata, Hiraiwa - Hasagawa, Kawanaka, Hayaki, Takasaki, Hesegawa and Kano to mention but a few, have always worked closely with the local people of Mahale. Thus, a checklist of names of plants, animals, insects, fish and birds of Mahale has been compiled and published in Japanese, Kitongwe and English. The Society plans to support and encourage this kind of research.

I have tried briefly to indicate the unique attributes of Mahale with its rich fauna and flora and accumulated data on chimpanzees obtained over a period of 30 years. Mahale needs to be protected as it is one of the world's best field laboratories for the study of Man's closest relatives. One of the objectives of the Society therefore, will be to support, wherever possible, field researchers and conservationists wishing to carry out research in Mahale. The kind of support will be determined as the Society grows and resources become available.

In conclusion, let me once again thank all of you for the support and honour you have given us in being with us at the inauguration of our Society this evening. We hope you will continue to show interest. We will keep you informed of the Society's achievements and accomplishments.

I thank you for your attention.

\section{An Inaugural Address by Toshisada Nishida Professor of Kyoto University}

Good afternoon Ladies and Gentlemen.

Today I am very happy to meet here with many people who understand the importance of wildlife conservation.

I have been studying the wild chimpanzees of the Mahale Mountains for almost three decades now. Allow me to explain why I have been involved with only one species of animal for such a long time. Chimpanzees have proved to be very charming animals who are so like us. For example, adult male chimpanzees have their own political strategies.

The current alpha male, Ntologi, is almost 40 years old but he has been able to keep his top position for as long as 15 years. At his side is his young, energetic rival, second-ranking Nsaba who wishes to take over the alpha status as such a position confers priority of matings with females and priority of access to delicious foods such as meat and ripe figs.

How can Ntologi maintain his top position for so many years despite his old age?

First, he often performs very impressive displays including rock-throwing, charging, branchdragging, branch-shaking, stamping or slapping tree butresses and so on. By combining these displays in his own unique way, he has succeeded in intimidating even the younger, physically stronger males.

Second, he has maintained his alliances with other males by grooming them earnestly and by sharing his meat with them. 